\title{
Water balance analysis in perennial river flow: case study Pulau Laut, South Kalimantan
}

\author{
Iman Muhardiono*, Hendri Sosiawan, and Anton Aprilyanto \\ Indonesian Agroclimate and Hydrology Research Institute (IAHRI) Jl. Tentara Pelajar No. 1A, \\ Bogor, Indonesia
}

\begin{abstract}
Water scarcity in dry land region is main problem which need to be solved as long the agricultural activity existed. The common technical way to sustain water is capturing rainfall and runoff and stored locally before they go through to the sea. Channel reservoir is simple water infrastructure or dam which consists of reinforced wall constructed by crossed a river channel to store run off flow and facilitate aquifer recharge. This paper aims to calculate a water balance to quantify the amount of water between the dam and hydrological system. Estimation of water balance is generated from rainfall data by Mock, Penman, and linked by mass conservation method. Volume of water during the dry season was gained consistently by 1964.53 $\mathrm{m} 3$ where it was above the minimum operation and the live storage capacity of this reservoir about 2,531 m3 where it was adequate to cover water demand for irrigation purpose. In conclusion, channel reservoir can utilize intermittent river channel to store water and be treated as isolated water storage structures with simple manufacture.
\end{abstract}

\section{Introduction}

FAO has defined drylands as those areas with a length of growing period of 1-179 days. Classification by the UNCCD employs a ratio of annual precipitation to potential evapotranspiration (P/PET) which are characterized between 0.05 and 0.65 [1]. This value indicates the maximum quantity of water capable of being lost, as water vapor, in a given climate, by a continuous stretch of vegetation covering the whole ground and well supplied with water. High variability in both rainfall intensities and amounts are characteristics of dryland regions as the occurrence of prolonged periods of drought. Drought is defined as a departure from the average of normal conditions, sufficiently prolonged as to affect the hydrological balance and adversely affect the ecosystem functioning and the resident populations[2,3].

Dryland farming systems vary according to socio-economic information, agro-ecology and possibilities for irrigation. The majority of the drylands used for agriculture is under cereal cultivation. Dryland farming is dependent solely on the water available from precipitation which stored into soil water at the time of seeding a crop to supplement the rainfall received during the growing season. With the development of dryland farming, waterconservation techniques had to be developed because moisture from seasonal precipitation was usually inadequate for crop growth and maturation. An important option for grain and

* Corresponding author: imanmuhardiono@gmail.com 
other agricultural production in drylands is water harvesting. Water harvesting which includes runoff farming, runoff storage, and dry farming using storage [4,5], can be less costly than irrigation and can be developed locally depending on rainfall and land conditions.

Controlling runoff is a primary objective of any dryland cropping system. Although total precipitation in dryland region is limiting, high intensity storms are common and the amounts of runoff can be significant. Several technologies and strategies have been developed that clearly demonstrate that the limited precipitation in dryland areas can be used more efficiently. Water harvesting as water management technique for growing crops in arid and semi-arid areas where rainfall is inadequate for rainfed production and irrigation water is lacking [6]. In order to gain improvement in management, the knowledge of water storage dynamic within this water infrastructure is required.

Channel reservoir is water infrastructure constructed to store water and commonly used in small to medium scale dryland farming especially in Indonesia. In several region such as Yogyakarta, Central Java, and West Java, channel reservoir can be utilized as irrigation supplementary to expand cultivation area, reducing drought risk, and extend cultivation period and reducing flood risk [7] also support to conserve the environment [8]. Channel reservoir is a reinforced concrete wall built across a perennial riverbed to harvest rainwater (Fig.1). After construction, the first seasonal rains fill the dam area with water. Character the material base (bed load) has highest settling velocity will be deposited in upstream of the dam while suspended material with smaller grain sizes, will be washed over the top of the dam and flow through the downstream. In principal water and soil conservation, the channel reservoir is carefully designed in order to keep the natural flow of the river is not altered and avoid erosion downstream of the dam.

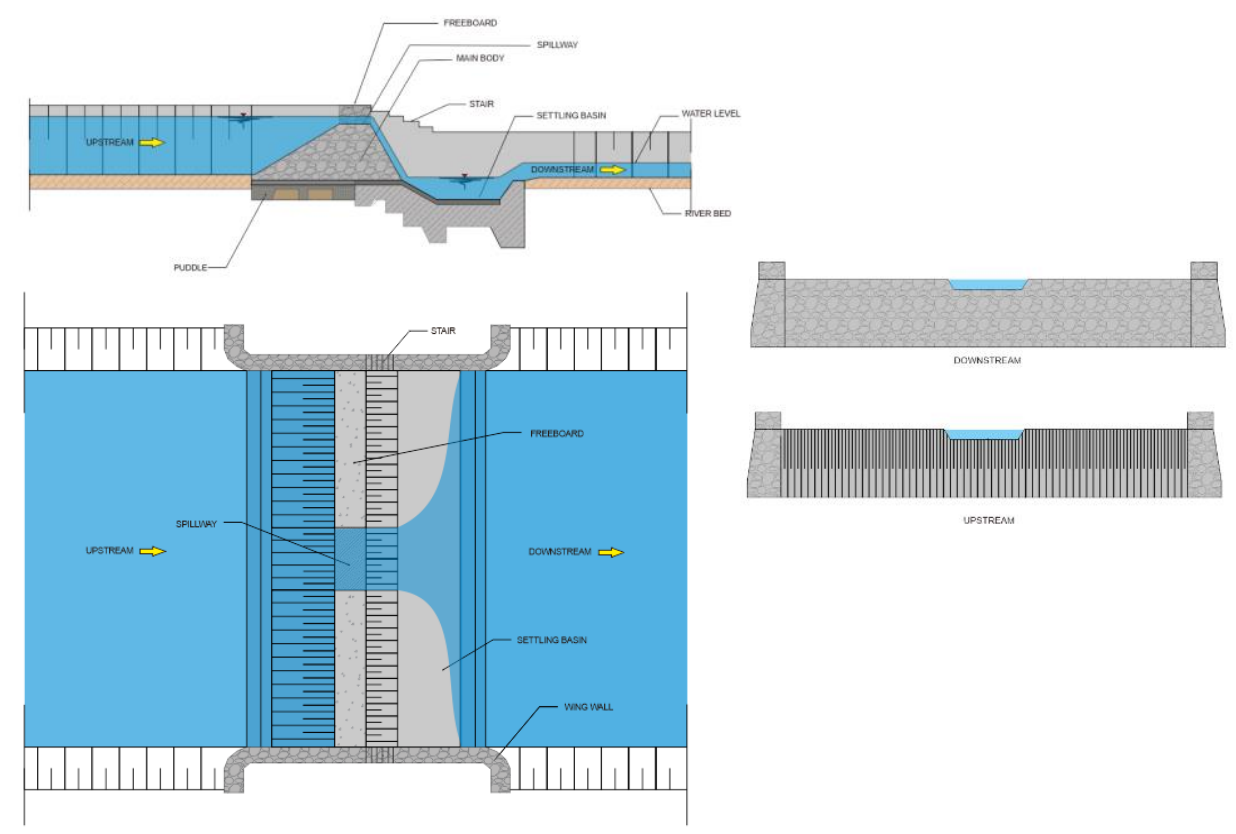

Fig. 1 Channel reservoir design in Pulau Laut, South Kalimantan

Dams are placed on straight stretches of river than bend. Spillway is built either in center or side main body with simple operation to flush when sediment deposit is gained into the top of minimum level of storage or pump inlet suction level. Wing walls are built to keep flood waters from going around the dam. The dam also obstructs groundwater naturally flowing through the permeable riverbed which creates higher upstream groundwater levels 
and also raising in those riverbanks [5]. The occurrence of water flow process still needs to be explored more since what extent dams can retain water where climate and soil aspect in local scale. The aim of this research is therefore to empirically test water balances as important component of hydrological. It can be measured and estimated accurately for example recharge including rainfall, runoff, and evapotranspiration process for storage reservoir during the seasonal period.

\section{Methods}

The study took place in South Pulau Laut, Kotabaru district, South Kalimantan province. Physiograph characteristic is dryland with hill region and slope less than $8 \%$ in the form of tectonic plains that develop from sandstone and claystone with shale, coal and limestone inserts. The climatic characteristics at the research location were analyzed based on climate data recorded at the Gusti Syamsir Alam Airport Meteorological Station, Kota Baru, South Kalimantan (station code according to WMO: 96695) which is located at a geographical position of -3.3 latitude and 116.17 east longitude, at an elevation of $2 \mathrm{~m}$ above sea level.

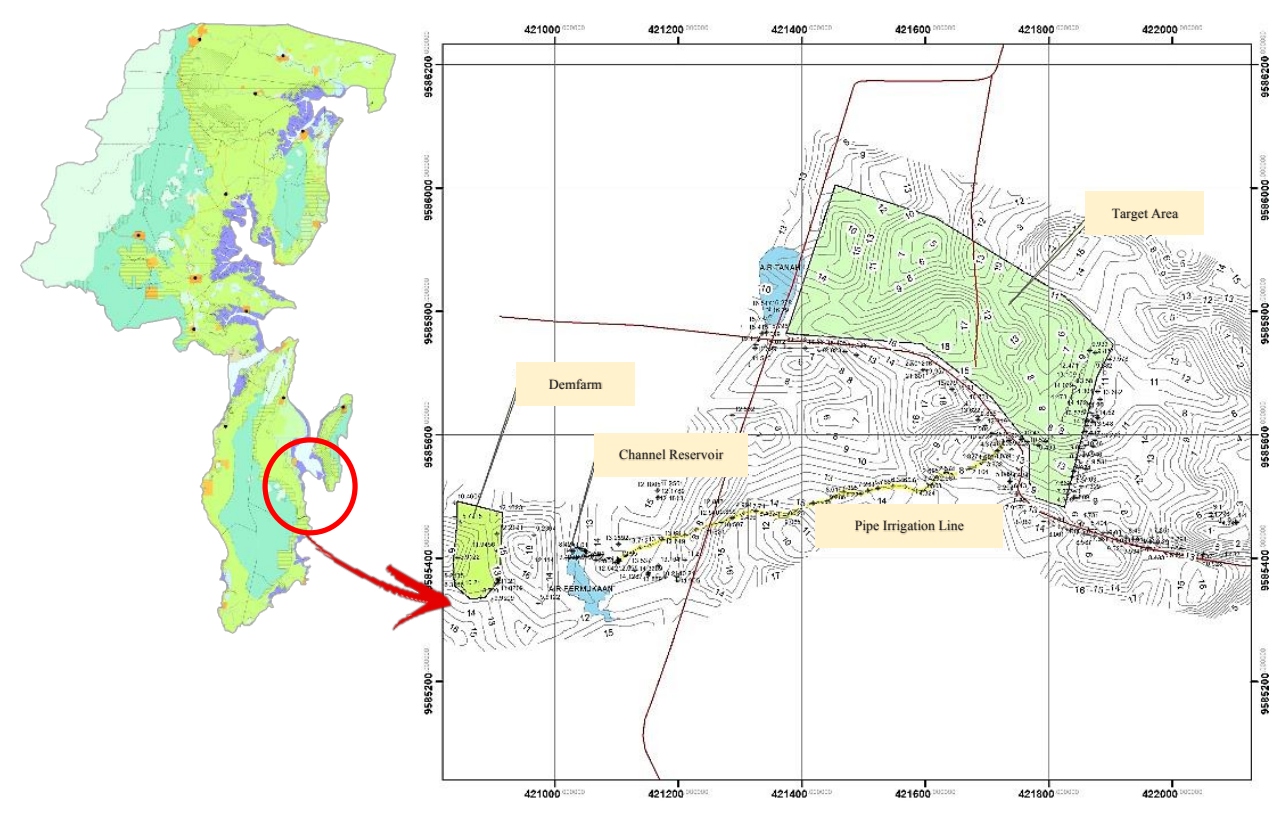

Fig. 2 Location of channel reservoir at Pulau Laut, South Kalimantan

Reservoir capacity is total capacity that can be storage by the reservoir. Reservoir capacity has active storage which can be utilized its volume to supply water demand and dead storage for sediment volume. The capacity of reservoir can be measured by topographical method using dam axis and contour elevation $5 \mathrm{~m}$ or $10 \mathrm{~m}$. Therefore, in every contour elevation determines the area, then the volume is gained between two sequence contour line. The volume between two contours line can be calculated as follow:

$$
V_{n}=\frac{1}{3} x \Delta h \times\left(F_{n-1}+F_{n}+\sqrt{F_{n} \times F_{n-1}}\right)
$$

where; $V_{n}=$ Volume at elevation $\mathrm{n}, \Delta h=$ different in height between two elevations, $F_{n-1}=$ inundation area before elevation $\mathrm{n}, F_{n}=$ inundation area in elevation $\mathrm{n}$. 
Live storage [9] is amounts of water which existed between outlet elevation into spillway elevation, meanwhile dead storage is amounts of water which existed below the outlet elevation. Then the live storage in reservoir can be calculated as follow:

$$
V_{\text {live storage }}=V_{\text {spillway }}-V_{\text {outlet }}
$$

Water balance in the reservoir describes balance condition between water inflow and outflow from its reservoir. Then it determines differences of storage volume $(\Delta S)$ the reservoir and follows continuity equation as:

$$
\begin{aligned}
& I-O= \pm \Delta S \\
& R+Q_{i}+G_{i}-E T o-Q_{o}-G_{o} \pm \Delta S=0
\end{aligned}
$$

where: $R=$ rainfall; $Q_{i}, Q_{o}=$ inflow and outflow; ETo = evapotranspiration; $G_{i}, G_{o}=$ baseflow in and out; $\Delta S=$ differences of storage volume. Evapotranspiration is influenced by temperature $(\mathrm{t})$, humidity $(\mathrm{RH})$, wind speed $(\mathrm{U})$, and radiation $(\mathrm{n} / \mathrm{N})$ which are connected each other. Number of evapotranspiration can be calculated by Penman modify formula [10] as:

$$
E T o=C(W \cdot R n+(1-W) \cdot f(U) \cdot(e a-e d)
$$

Dr. F.J. Mock had developed formula to calculate the water availability $[11,12]$. Principally, Mock method refer to water balance, uses daily rainfall data, evapotranspiration, and hydrologic watershed characteristic to model as good alternative tool for rapid watershed assessment, particularly in the regions with limited hydrological data. A flowchart of the calculation is shown in (Fig.3) below.

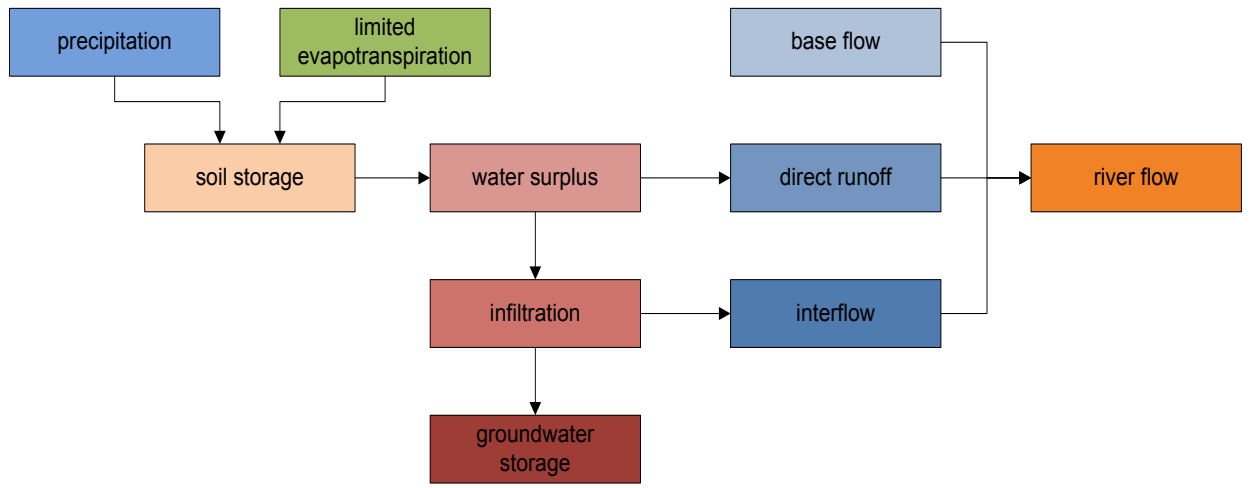

Fig. 3. Schematic discharge calculation by F.J. Mock methods

The water balance estimation is basically based on the principle of mass conservation, often referred to the storage equation where the difference between the total inflow and outflow is balance by the change in storage over a given time period [13]. The general water balance for single reservoir for a given time period may be expressed as given in the following equation:

$$
\begin{aligned}
& \Delta V_{s}=V_{r}+V_{p c p}+V_{\text {Gin }}-V_{s p}-V_{\text {evap }}-V_{\text {inf }}-V_{w d} \\
& \frac{\Delta V}{\Delta T}=(I-O)
\end{aligned}
$$

where $\Delta V_{s}=$ change of water storage in the reservoir at time step; $V_{r}=$ runoff into the reservoir; $V_{\text {Gin }}=$ groundwater inflow from aquifer to reservoir; $V_{s p}=$ spills out the reservoir; $V_{w d}=$ water withdrawal; $V_{p c p}$ and $V_{\text {evap }}=$ rainfall onto and evaporation from the reservoir surface area; and $V_{\text {inf }}=$ infiltration loss from the reservoir 


\section{Results}

\subsection{Hydro-climatology and evapotranspiration analysis}

Climatology data was used from 2010-2019 year. The minimum temperature during the period 2019 ranges from $21^{\circ} \mathrm{C}$ to $26^{\circ} \mathrm{C}$, while the maximum temperature ranges from $24.9^{\circ} \mathrm{C}$ to $35.1^{\circ} \mathrm{C}$. The average annual humidity of $82 \%$ ranges from 43 to $97 \%$. The average annual irradiation time is 5.6 hours.day ${ }^{-1}$ with the lowest irradiation time of 0 hours and the highest is 11.5 hours.day ${ }^{-1}$. The maximum wind speed during the year averages $4.2 \mathrm{~m} \mathrm{~s}^{-1}$, with the lowest maximum wind speed of $2 \mathrm{~m} \mathrm{~s}^{-1}$ and the highest wind speed of $12 \mathrm{~m} \mathrm{~s}^{-1}$. The most dominant wind direction throughout the year is the wind from the South, followed by the wind direction from the North. The annual rainfall at the research location is 2,063.8 $\mathrm{mm}$ year $^{-1}$. Monthly rainfall data recapitulation results are shown in (Table.1).

Based on the climate type criteria Schmidt \& Ferguson [14], the research location was included in the $\mathrm{C}$ climate type criteria which was characterized by 8 wet months $(\mathrm{R}>100$ month $^{-1}$ ), 3 dry months (rainfall $\left.<60 \mathrm{~mm} \mathrm{month}^{-1}\right)$ and 1 humid month $(100>\mathrm{R}>60)$. Meanwhile, according to the criteria for the Agro-climate Zone Oldeman [15], the study area was included in the B2 Agro-climate zone which was characterized by 8 wet months $(R>200$ month $\left.^{-1}\right)$ and 3 dry months $\left(\mathrm{R}<100 \mathrm{~mm} \cdot \mathrm{month}^{-1}\right)$. The maximum daily rainfall for the last 10 years (2010 to 2019) is at $98 \mathrm{~mm} \mathrm{day}^{-1}$, and the maximum that has ever happened is 135.4 $\mathrm{mm}$ day $^{-1}$. In the last 10 years, the lowest average monthly rainfall in August was $62 \mathrm{~mm}$ month $^{-1}$, and the highest was in January at $252 \mathrm{~mm} \mathrm{month}^{-1}$ (Fig.3).

Table 1. Monthly rainfall at Syamsir Alam Station $\left(\mathrm{mm} \mathrm{month}{ }^{-1}\right)$

\begin{tabular}{crrrrrrrrrrrrr}
\hline No. & Year & Jan & Feb & Mar & Apr & May & Jun & Jul & Aug & Sep & Oct & Nov & Dec \\
\hline 1 & 2009 & 345 & 218 & 183 & 120 & 106 & 74 & 58 & 11 & 2 & 100 & 346 & 291 \\
2 & 2010 & 397 & 188 & 240 & 200 & 294 & 392 & 609 & 327 & 282 & 394 & 230 & 208 \\
3 & 2011 & 410 & 143 & 229 & 292 & 94 & 53 & 189 & 10 & 182 & 219 & 106 & 176 \\
4 & 2013 & 250 & 244 & 386 & 132 & 163 & 232 & 332 & 262 & 371 & 104 & 349 & 259 \\
5 & 2014 & 151 & 184 & 373 & 100 & 186 & 268 & 37 & 212 & 67 & 20 & 105 & 309 \\
6 & 2015 & 88 & 21 & 0 & 0 & 0 & 0 & 9 & 20 & 0 & 139 & 0 & 286 \\
7 & 2016 & 121 & 149 & 341 & 178 & 131 & 158 & 67 & 102 & 182 & 237 & 193 & 201 \\
8 & 2017 & 304 & 263 & 150 & 106 & 327 & 412 & 304 & 119 & 50 & 178 & 165 & 102 \\
9 & 2018 & 87 & 142 & 230 & 71 & 131 & 381 & 184 & 94 & 50 & 73 & 219 & 223 \\
10 & 2019 & 244 & 229 & 222 & 251 & 108 & 497 & 46 & 14 & 7 & 80 & 179 & 189 \\
\hline & Min & 87 & 21 & 0 & 0 & 0 & 0 & 9 & 10 & 0 & 20 & 0 & 102 \\
& Q1 & 128 & 144 & 192 & 102 & 106 & 95 & 49 & 15 & 18 & 85 & 121 & 192 \\
& Q2 & 247 & 186 & 229 & 126 & 131 & 250 & 125 & 98 & 58 & 122 & 186 & 215 \\
& Q3 & 335 & 226 & 316 & 195 & 180 & 390 & 275 & 189 & 182 & 209 & 227 & 279 \\
& Max & 410 & 263 & 386 & 292 & 327 & 497 & 609 & 327 & 371 & 394 & 349 & 309 \\
\hline
\end{tabular}




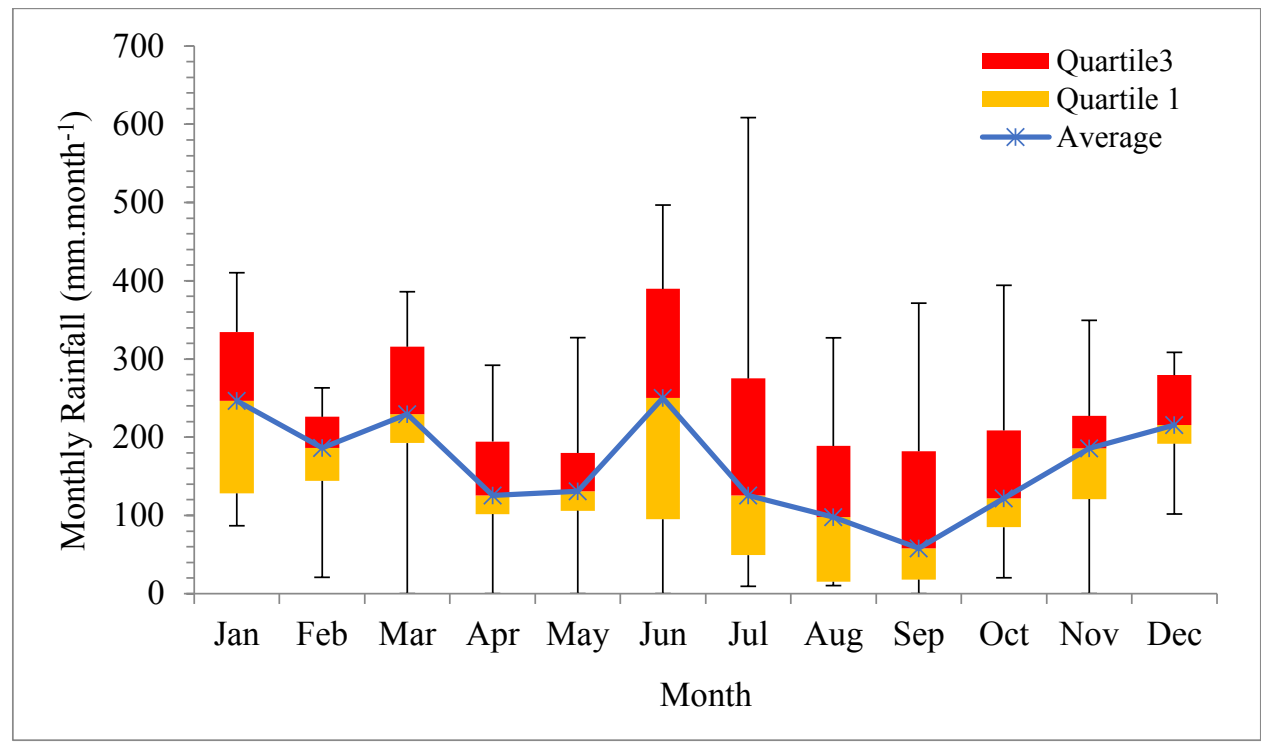

Fig. 4 Monthly rainfall graph at Syamsir Alam's station

Evapotranspiration monthly based on Penman modify method show the lowest condition existed on June with $2.23 \mathrm{~mm} \mathrm{month}^{-1}$ it was seemed increasing gradually into the highest peak on September with $3.61 \mathrm{~mm}$ month $^{-1}$. This evapotranspiration value will influence amount of inflow discharge which was entered into the reservoir based on Mock method. This calculation was conducted every year of available data, then the results data was sorted from biggest into smallest, and determined which one is $80 \%$ reliable.

Based on water balance analysis (Table.2), the highest average monthly discharge gained in June with $0.891 \times 10^{-3} \mathrm{~m}^{3} \cdot \mathrm{s}^{-1}$, and the lowest gained in October with $0.357 \times 10^{-3} \mathrm{~m}^{3} \cdot \mathrm{s}^{-1}$. Those phenomena were matched by existing climate condition where at that month is dry season indeed. By simulation of Q80 discharge was gained from 2018 years data, with monthly discharge about $0.039 \times 10^{-3} \mathrm{~m}^{3} \cdot \mathrm{s}^{-1}$ and Q90 from 2015 years data about $0.003 \times 10^{-3} \mathrm{~m}^{3} \cdot \mathrm{s}^{-1}$ (Fig.4).

Table 2. Monthly discharge $\left(\mathrm{x} 10^{-3} \mathrm{~m}^{3} \cdot \mathrm{s}^{-1}\right)$

\begin{tabular}{ccccccccccccc}
\hline Year & Jan & Feb & Mar & Apr & May & Jun & Jul & Aug & Sept & Oct & Nov & Dec \\
\hline 2009 & 1.325 & 0.892 & 0.699 & 0.449 & 0.349 & 0.196 & 0.097 & 0.058 & 0.035 & 0.021 & 0.315 & 0.789 \\
2010 & 1.290 & 0.668 & 0.819 & 0.701 & 1.069 & 1.515 & 2.416 & 1.493 & 1.172 & 1.485 & 0.931 & 0.762 \\
2011 & 1.461 & 0.598 & 0.771 & 1.059 & 0.395 & 0.200 & 0.598 & 0.162 & 0.169 & 0.491 & 0.155 & 0.349 \\
2013 & 0.653 & 0.731 & 1.306 & 0.551 & 0.598 & 0.852 & 1.206 & 0.990 & 1.343 & 0.423 & 1.210 & 0.928 \\
2014 & 0.500 & 0.592 & 1.263 & 0.432 & 0.632 & 0.964 & 0.267 & 0.561 & 0.171 & 0.103 & 0.062 & 0.502 \\
2015 & 0.128 & 0.069 & 0.042 & 0.025 & 0.015 & 0.009 & 0.005 & 0.003 & 0.002 & 0.001 & 0.001 & 0.000 \\
2016 & 0.110 & 0.256 & 0.995 & 0.572 & 0.400 & 0.495 & 0.157 & 0.147 & 0.347 & 0.570 & 0.513 & 0.532 \\
2017 & 0.925 & 0.908 & 0.496 & 0.336 & 1.110 & 1.577 & 1.276 & 0.536 & 0.269 & 0.294 & 0.362 & 0.140 \\
2018 & 0.075 & 0.257 & 0.617 & 0.152 & 0.324 & 1.300 & 0.726 & 0.297 & 0.160 & 0.096 & 0.221 & 0.507 \\
2019 & 0.667 & 0.706 & 0.699 & 0.846 & 0.399 & 1.802 & 0.412 & 0.247 & 0.148 & 0.089 & 0.053 & 0.044 \\
\hline Sum & 7.134 & 5.679 & 7.706 & 5.123 & 5.291 & 8.912 & 7.161 & 4.495 & 3.817 & 3.573 & 3.823 & 4.555 \\
Max & 1.461 & 0.908 & 1.306 & 1.059 & 1.110 & 1.802 & 2.416 & 1.493 & 1.343 & 1.485 & 1.210 & 0.928 \\
Min & 0.075 & 0.069 & 0.042 & 0.025 & 0.015 & 0.009 & 0.005 & 0.003 & 0.002 & 0.001 & 0.001 & 0.000 \\
Avg & 0.713 & 0.568 & 0.771 & 0.512 & 0.529 & 0.891 & 0.716 & 0.449 & 0.382 & 0.357 & 0.382 & 0.455 \\
\hline
\end{tabular}




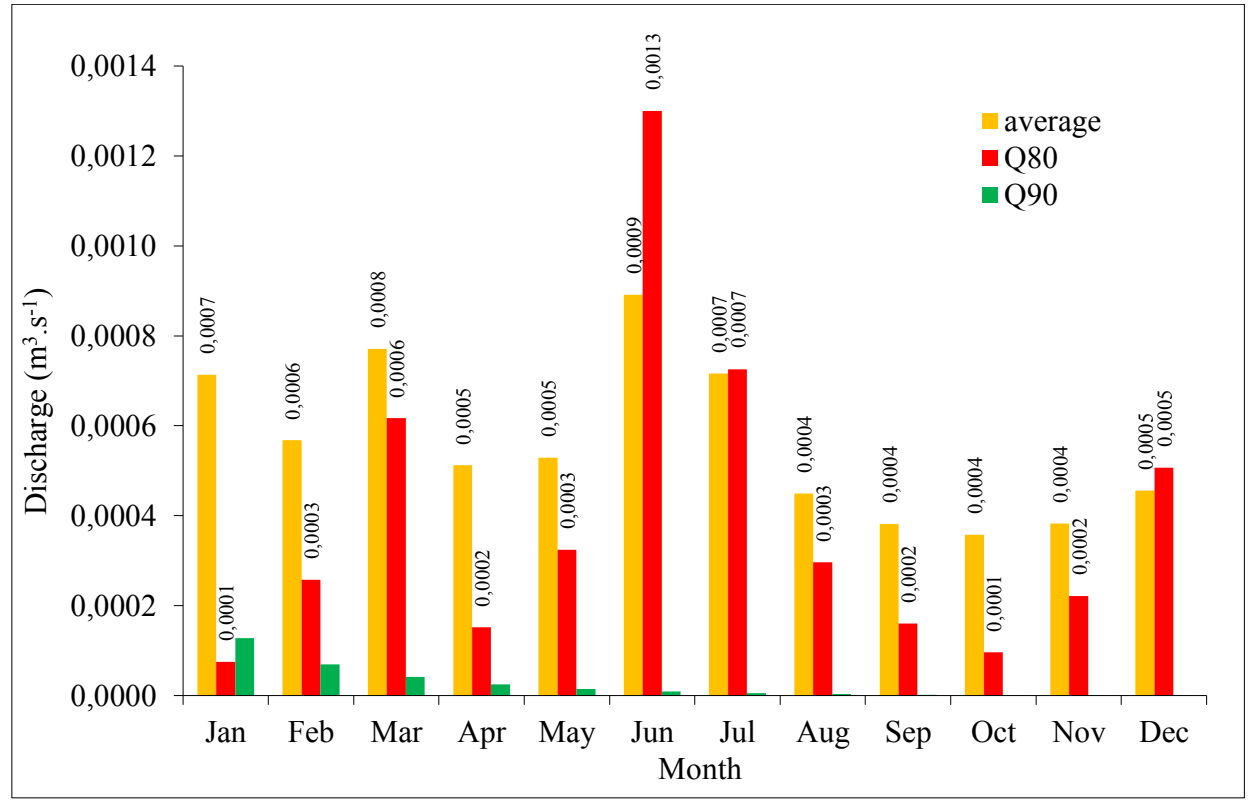

Fig. 5 Water balance graph

\subsection{Summary of water balance in reservoir}

An elevation model of reservoir is elevation-storage relationship. The range and interval of elevation to use for storage calculations. By design, the dam crest was gained about $1.8 \mathrm{~m}$ height $(+5.63 \mathrm{~m}$ asl) or from bed elevation $(+3.88 \mathrm{~m}$ asl). Maximum storage volume at $(+5.58$ $\mathrm{m}$ asl) was $2,814 \mathrm{~m}^{3}$ (Fig.5). Since the criteria of type channel reservoir must be below 3,000 $\mathrm{m}^{3}$ for small scale purpose, the dam was able to be used for irrigation agriculture then.

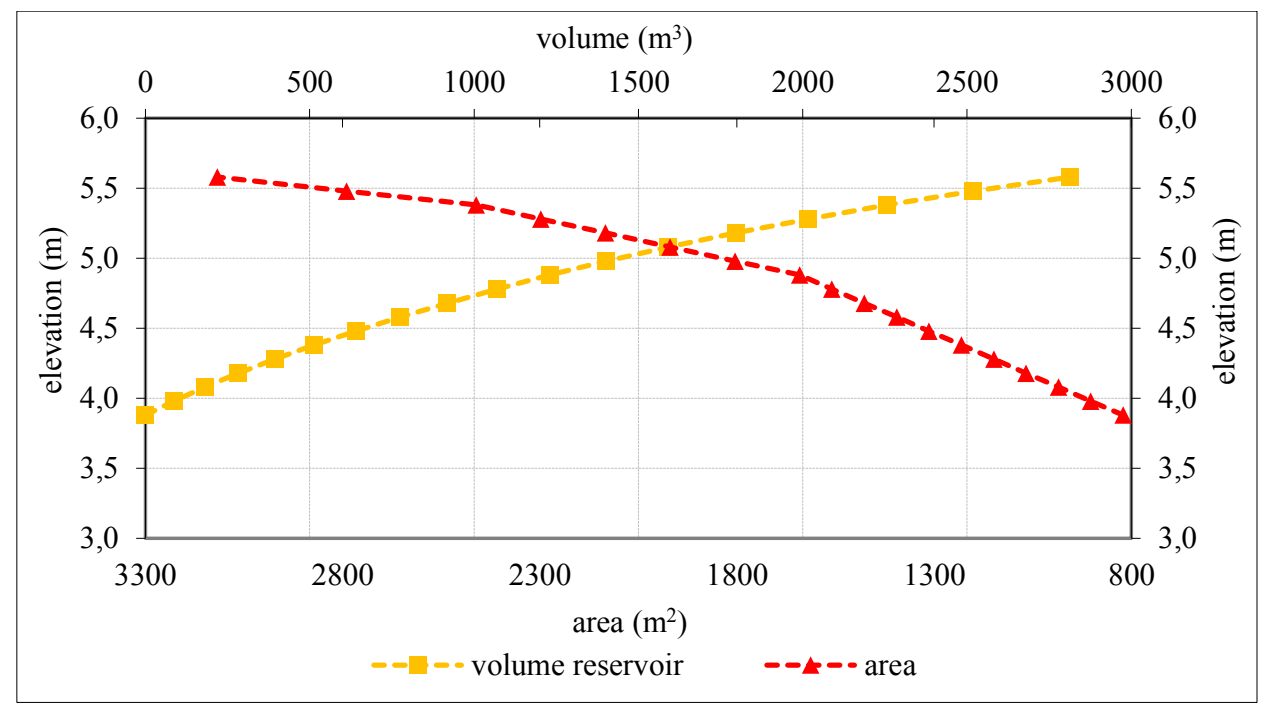

Fig. 6 Relationship graph between volume and storage area reservoir 
Water balance in reservoir was carried out as consideration to estimate availability for irrigation purposes in dry season where it will be influenced by overflow water at spillway and also impacted by evaporation and water use. Equation 2 and equation 5 was used to simulate amounts of inflow discharge and outflow which can be differences $\left(\Delta V_{s}\right)$ for the reservoir.

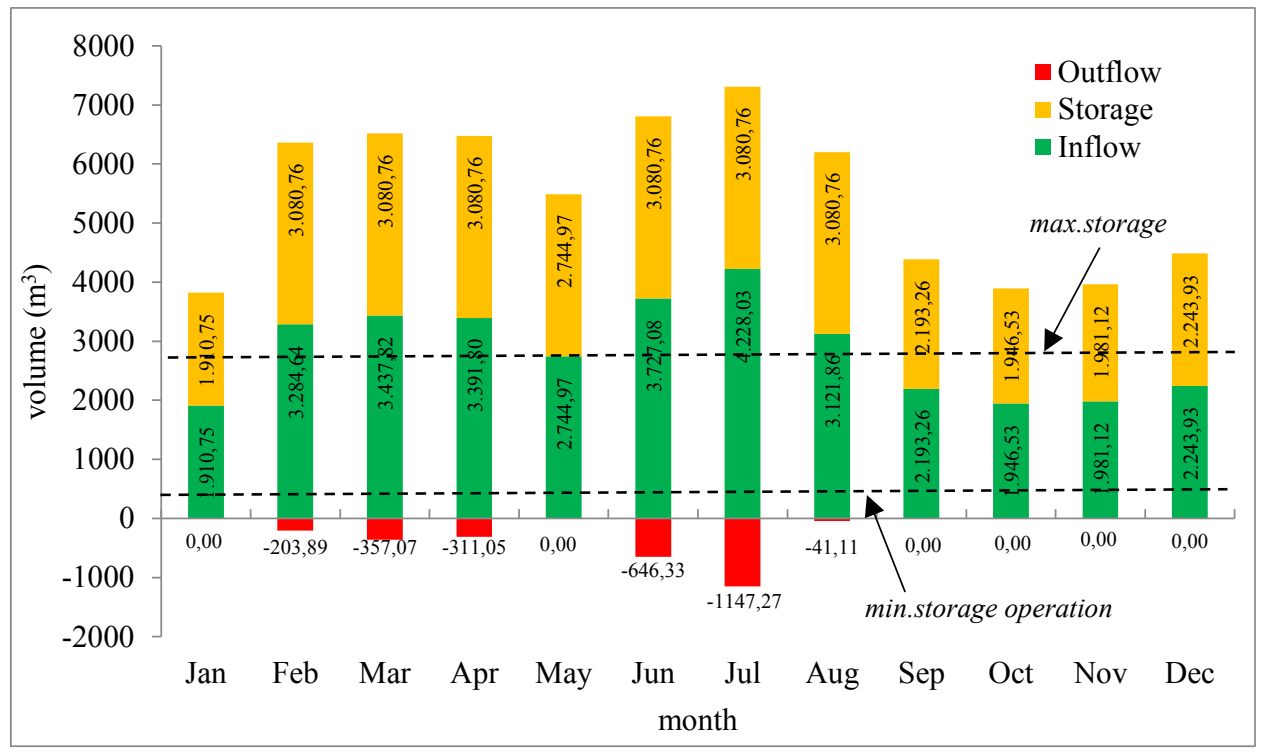

Fig. 7. Water balance in channel reservoir

Fig. 6 show that in June the reservoir will be gained maximum peak storage by volume to $3,080.76 \mathrm{~m}^{3}$ where the excess of water will be spilled out into downstream about $1,147.27$ $\mathrm{m}^{3}$. Furthermore, after that until October the volume will decrease gradually and gain into $1964.53 \mathrm{~m}^{3}$ at $+5.15 \mathrm{~m}$ asl. Spillway elevation to the reference at $+5.63 \mathrm{~m}$ asl and pump inlet suction for water use at $+4.18 \mathrm{~m}$ asl. Based on reservoir capacity analysis (Fig.5), the volume at spillway elevation $\left(+5.63 \mathrm{~m}\right.$ asl) was $3,080.76 \mathrm{~m}^{3}$ and volume at pump inlet suction was $283.05 \mathrm{~m}^{3}$ for minimum storage operation. The live storage was $2,531 \mathrm{~m}^{3}$.

\section{Conclusion}

Water balance analysis at channel reservoir to water demand irrigation at dry season can be concluded that maximum reliability $80 \%$ inflow discharge was conducted in June with $0.039 \times 10^{-3} \mathrm{~m}^{3} \cdot \mathrm{s}^{-1}$ meanwhile the minimum reliability inflow was gained two times in April with $0.015 \times 10^{-3} \mathrm{~m}^{3} \cdot \mathrm{s}^{-1}$ and October with $0.010 \times 10^{-3} \mathrm{~m}^{3} \cdot \mathrm{s}^{-1}$. Water balance analysis showed that the monthly average water deficit was concluded in October with $0.357 \times 10^{-3} \mathrm{~m}^{3} \cdot \mathrm{s}^{-1}$ by volume $1964.53 \mathrm{~m}^{3}$ as inflow at storage reservoir. The storage $\Delta V s$ in October still above the minimum pump operation where it can be saved to be used to irrigate the land. Nevertheless, the live storage capacity of this reservoir about $2,531 \mathrm{~m}^{3}$ can be optimized to irrigate $2 \mathrm{Ha}$ dry land once a month for maize $\left(0.51 . \mathrm{s}^{-1} . \mathrm{ha}^{-1}\right)$ as example. Finally, the channel reservoir can upscale capability of natural resource with only has perennial river to serve water and reduce drought risk in dry land agricultural system. 
Acknowledgements. The authors would like to acknowledge to Indonesian Agency of Agricultural Research and Development for funding this research and also would like to thank Dr.Ir. Fadjry Djufry for supporting so this research activities can be carried out. I M and H S are main contributors in this paper.

\section{References}

1. P. Koohafkan, B.A. Stewart. Water and cereals in drylands (London: FAO of The United Nations and Earthscan, 2012)

2. R.A.B. Kpadonou, T. Owiyo, B. Barbier, F. Denton, F. Rutabingwa, A. Kiema. Land use policy 61, (2017)

3. S. Mukherjee, A. Mishra, K.E. Trenberth. Curr. Clim. Chang. Reports 4, (2018)

4. R. Quinn, K. Rushton, A. Parker. J. Hydrol. 4, (2019)

5. C. Ryan, P. Elsner. Reg. Environ. Chang. 16, (2016)

6. N. Heryani, B. Kartiwa, A. Hamdani, I. Muhardiono, B. Rahayu, Purwaningasih. Rainwater harvesting technology to increase cropping index under perennial crops IOP Conf. Ser. Earth Environ. Sci. (2021)

7. I. Muhardiono, A. Hamdani. Flood vulnerability impact for food estate potential in Central Kalimantan, Indonesia IOP Conf. Ser. Earth Environ. Sci. (2021)

8. N. Heryani, H. Sosiawan, S.H. Adi. J. Sumberdaya Air, 10, (2014)

9. M. Mudjiatko, A.S. Agus. Spektrum Sipil 2, (2017)

10. A. Gazali. J. Keilmuan Teknik Sipil 2, (2020)

11. D. Chandrasasi, L. Montarcih, W.R. Juni.Analysis using the F. J. Mock Method for calculation of water balance in the Upper Konto Sub-Watershed. IOP Conf. Ser. Earth Environ. Sci. (2020)

12. Jihad, J. Ilmu Desain Konstr. 17, (2018)

13. T. Fowe, H. Karambiri, J.E. Paturel, J.C. Poussin, P. Cecchi. Agric. Water Manag. 152, (2015)

14. M. Irfan. The Determination of Palembang Climate Type by Using Schmidt-Ferguson Method. Int. Conf. Sustain. Energy Environ. (SEE 2006) Bangkok Thail. (2006)

15. Oldeman L R. Agro-climatic map of Java. (1975) 